\title{
Études/Inuit/Studies
}

\section{Revue des revues} Survey of periodicals

Volume 39, numéro 2, 2015

URI : https://id.erudit.org/iderudit/1038158ar

DOI : https://doi.org/10.7202/1038158ar

Aller au sommaire du numéro

\section{Éditeur(s)}

Centre interuniversitaire d'études et de recherches autochtones (CIÉRA)

\section{ISSN}

0701-1008 (imprimé)

1708-5268 (numérique)

Découvrir la revue

Citer ce document

(2015). Revue des revues / Survey of periodicals. Études/Inuit/Studies, 39(2), 317-325. https://doi.org/10.7202/1038158ar d'utilisation que vous pouvez consulter en ligne.

https://apropos.erudit.org/fr/usagers/politique-dutilisation/ 


\title{
Revue des revues / Survey of periodicals
}

\author{
Anthropologie / Anthropology
}

AYLWARD, Erin, Nadia ABU-ZAHRA, Audrey GILES

2015 Mobility and Nunavut Inuit youth: Lessons from Northern Youth Abroad, Journal of Youth Studies, 18(5): 553-568.

BROWN TRINIDAD, Susan et al.

2015 Community dissemination and genetic research: Moving beyond results reporting, American Journal of Medical Genetics Part A, 167(7): 15421550.

\section{BRUNGER, Fern, Todd RUSSELL}

2015 Risk and representation in research ethics: The NunatuKavut experience, Journal of Empirical Research on Human Research Ethics, 10(4): 368-379.

BUDACH, Gabriele, Donna PATRICK, Teevi MACKAY

2015 "Talk around objects": Designing trajectories of belonging in an urban Inuit community, Social Semiotics, 25(4): 446-464.

BUTTON KAMBIC, Emily

2015 The changing lives of women's knives: ulus, travel, and transformation, Historical Archaeology, 49(3): 35-53.

DUTHEIL, April, Frank TESTER, Jordan KONEK

2015 Unequal exchange: Western economic logic and Inuit/Qablunaat research relationships, Polar Record, 51(2): 140-150.

\section{GOMBAY, Nicole}

2015 "There are mentalities that need changing": Constructing personhood, formulating citizenship, and performing subjectivities on a settler colonial frontier, Political Geography, 48: 11-23.

JOHNSON, Noor et al.

2015 The contributions of community-based monitoring and traditional knowledge to Arctic observing networks: Reflections on the state of the field, Arctic, 68: 28-40. 
PASCH, Timothy J.

2015 Towards the enhancement of Arctic digital industries: "Translating" cultural content to new media platforms, Journal of Specialised Translation, 24: $187-213$.

SOWA, Frank

2015 Kalaalimernit: The Greenlandic taste for local foods in a globalised world, Polar Record, 51(3): 290-300.

\section{Archéologie / Archaeology}

BETTS, Matthew W., Mari HARDENBERG, Ian STIRLING

2015 How animals create human history: Relational ecology and the Dorset-polar bear connection, American Antiquity, 80(1): 89-112.

LYNNERUP, Niels

2015 The Thule Inuit mummies from Greenland, Anatomical Record-Advances in Integrative Anatomy and Evolutionary Biology, 298(6): 1001-1006.

MISARTI, Nicole, Herbert D. G. MASCHNER

2015 The Paleo-Aleut to Neo-Aleut transition revisited, Journal of Anthropological Archaeology, 37: 67-84.

PRENTISS, Anna Marie et al.

2015 Cultural macroevolution among high latitude hunter-gatherers: A phylogenetic study of the Arctic Small Tool tradition, Journal of Archaeological Science, 59: 64-79.

RAFF, Jennifer A. et al.

2015 Mitochondrial diversity of Iñupiat people from the Alaskan North Slope provides evidence for the origins of the Paleo- and Neo-Eskimo peoples, American Journal of Physical Anthropology, 157(4): 603-614.

ROY, Natasha, James WOOLLETT, Najat BHIRY

2015 Paleoecological perspectives on landscape history and anthropogenic impacts at Uivak Point, Labrador, since AD 1400, Holocene, 25(11): 17421755.

SUTHERLAND, Patricia D., Peter H. THOMPSON, Patricia A. HUNT

2015 Evidence of early metalworking in Arctic Canada, Geoarchaeology, 30(1): 74-78.

WALLS, Matthew, Pauline KNUDSEN, Frederik LARSEN

2015 Inughuit open water hunting before the Nineteenth Century: New dates and questions from Washington land, Northwest Greenland, American Antiquity, 80(3): 602-609. 
Arts

SCHWAN, Kaitlin Jessica, Ernie LIGHTMAN

2015 Fostering resistance, cultivating decolonization: The intersection of Canadian colonial history and contemporary arts programming with Inuit youth, Cultural Studies-Critical Methodologies, 15(1): 15-29.

\section{Criminologie / Criminology}

STEWART, Lynn A. et al.

2015 The effectiveness of the Tupiq Program for Inuit Sex Offenders, International Journal of Offender Therapy and Comparative Criminology, 59(12): 1338-1357.

\section{Droit / Law}

BERNAUER, Warren

2015 The Nunavut land claims agreement and caribou habitat management, Canadian Journal of Native Studies, 35(1): 5-32.

KINGSTON, Lindsey

2015 The destruction of identity: Cultural genocide and Indigenous peoples, Journal of Human Rights, 14(1): 63-83.

\section{Économie / Economy}

BEAUMIER, Maude C., James FORD, Shirley TAGALIK

2015 The food security of Inuit women in Arviat, Nunavut: The role of socioeconomic factors and climate change, Polar Record, 51(5): 550-559.

COX, David, Suzanne MILLS

2015 Gendering Environmental Assessment: Women's participation and employment outcomes at Voisey's Bay, Arctic, 68(2): 246-260.

DUHAIME, Gérard, Roberson ÉDOUARD

2015 Monetary poverty in Inuit Nunangat, Arctic, 68(2): 223-232.

GUO, Yang et al.

2015 Seasonal prevalence and determinants of food insecurity in Iqaluit, Nunavut, International Journal of Circumpolar Health, 74: article 27284.

HENDRIKSEN, Kåre, Ulrik JØRGENSEN

2015 Hunting and fishing settlements in Upernavik district of Northern Greenland - challenged by climate, centralization, and globalization, Polar Geography, 38(2): 123-146. 


\section{LORING, Philip A., S. Craig GERLACH}

2015 Searching for progress on food security in the North American North: A research synthesis and meta-analysis of the peer-reviewed literature, Arctic, 68(3): 380-392.

\section{SELLHEIM, Nikolas}

2015 The goals of the EU seal products trade regulation: From effectiveness to consequence, Polar Record, 51(3): 274-290.

\section{Éducation / Education}

HARCHAREK, Pausauraq Jana, Cathy Tagnak REXFORD

2015 Remembering their words, evoking kinuniivut: the development of the Iñupiaq learning framework, Journal of American Indian Education, 54(2): 9-28.

KENNEDY DALSEG, Sheena

2015 Creating citizens, building societies? Adult education in the Eastern Arctic as if community mattered, Historical Studies in Education-Canada, 27(1): $99-120$

McGREGOR, Catherine A.

2015 Creating able human beings: Social studies curriculum in the Northwest Territories and Nunavut, 1969 to the present, Historical Studies in Education-Canada, 27(1): 57-79.

McGREGOR, Heather E.

2015 Listening for more (hi)stories from the Arctic's dispersed and diverse educational past, Historical Studies in Education-Canada, 27(1): 19-39.

McMILLAN, Barbara

2015 Educating for cultural survival in Nunavut: Why haven't we learned from the past?, Paideusis-The Journal of the Canadian Philosophy of Education Society, 22(2): 24-37.

\section{Environnement / Environment}

CHAMPALLE, Clara, James FORD, Mya SHERMAN

2015 Prioritizing climate change adaptations in Canadian Arctic communities, Sustainability, 7(7): 9268-9292.

CUERRIER, Alain et al.

2015 The study of Inuit knowledge of climate change in Nunavik, Quebec: A mixed methods approach, Human Ecology, 43(3): 379-394. 
DURKALEC, Agata, Chris FURGAL, Mark W. SKINNER, Tom SHELDON

2015 Climate change influences on environment as a determinant of Indigenous health: Relationships to place, sea ice, and health in an Inuit community, Social Science and Medicine, 136: 17-26.

MacDONALD, Joanna Petrasek et al.

2015 Protective factors for mental health and well-being in a changing climate: Perspectives from Inuit youth in Nunatsiavut, Labrador, Social Science and Medicine, 141: 133-141.

PEARCE, Tristan, James FORD, Ashlee Cunsolo WILLOX, Barry SMIT

2015 Inuit Traditional Ecological Knowledge (TEK), subsistence hunting and adaptation to climate change in the Canadian Arctic, Arctic, 68(2): 233-245.

RATHWELL, Kaitlyn Joanne, Derek ARMITAGE, Fikret BERKES

2015 Bridging knowledge systems to enhance governance of the environmental commons: A typology of settings, International Journal of the Commons, 9(2): 851-880.

STATHAM, Sara et al.

2015 Anomalous climatic conditions during winter 2010-2011 and vulnerability of the traditional Inuit food system in Iqaluit, Nunavut, Polar Record, 51(3): 301-317.

WILLOX, Ashlee Cunsolo et al.

2015 Examining relationships between climate change and mental health in the Circumpolar North, Regional Environmental Change, 15(1): 169-182.

\section{Géographie / Geography}

SCASSA, Teresa, Nate J. ENGLER, D. R. Fraser TAYLOR

2015 Legal issues in mapping traditional knowledge: Digital cartography in the Canadian North, Cartographic Journal, 52(1): 41-50.

\section{Histoire / History}

BROWN, S. K., C. M. DARWENT, E. J. WICTUM, B. N. SACKS

2015 Using multiple markers to elucidate the ancient, historical and modern relationships among North American Arctic dog breeds, Heredity, 115(6): 488-495.

PERKINS, Robert A.

2015 Oil spill, August 1944: The CULA expedition and the North Slope Inupiat, Polar Record, 51(2): 201-211. 


\section{Linguistique / Linguistics}

ALLEN, Shanley E. M., Catherine DENCH

2015 Calculating mean length of utterance for eastern Canadian Inuktitut, First Language, 35(4-5): 377-406.

CAMERON, Emilie, Rebecca MEARNS, Janet Tamalik McGRATH

2015 Translating climate change: Adaptation, resilience, and climate politics in Nunavut, Canada, Annals of The Association of American Geographers, 105(2): 274-283.

GRAF, Eileen, Anna THEAKSTON, Elena LIEVEN, Michael TOMASELLO

2015 Subject and object omission in children's early transitive constructions: A discourse-pragmatic approach, Applied Psycholinguistics, 36(3): 701-727.

HAYASHI, Midori, David Y. OSHIMA

2015 How multiple past tenses divide the labor: The case of South Baffin Inuktitut, Linguistics, 53(4): 773-808.

KELLY, Barbara F. et al.

2015 Linguistic diversity in first language acquisition research: Moving beyond the challenges, First Language, 35(4-5): 286-304.

\section{SHERKINA-LIEBER, Marina}

2015 Tense, aspect, and agreement in heritage Labrador Inuttitut: Do receptive bilinguals understand functional morphology?, Linguistic Approaches To Bilingualism, 5(1): 30-61.

SHERKINA-LIEBER, Marina, Rena HELMS-PARK

2015 A prototype of a receptive lexical test for a polysynthetic heritage language: The case of Inuttitut in Labrador, Language Testing, 32(4): 419-442.

VOVIN, Alexander

2015 Eskimo Loanwords in Northern Tungusic, Iran and the Caucasus, 19(1): 87-95.

\section{Politique / Politics}

SELLHEIM, Nikolas

2015 The goals of the EU seal products trade regulation: From effectiveness to consequence, Polar Record, 51(3): 274-290. 


\section{Psychologie / Psychology}

\section{BJERREGAARD, Peter, Christina Viskum LYTKEN LARSEN}

2015 Time trend by region of suicides and suicidal thoughts among Greenland Inuit, International Journal of Circumpolar Health, 74: article 26053.

\section{BJOERKSTEN, Karin S., Peter BJERREGAARD}

2015 Season of birth is different in Inuit suicide victims born into traditional than into modern lifestyle: A register study from Greenland, BMC Psychiatry, 15: article 147.

BURTON, Peter, Angela DALEY, Shelley PHIPPS

2015 The well-being of adolescents in Northern Canada, Child Indicators Research, 8(3): 717-745.

CHACHAMOVICH, Eduardo et al.

2015 Suicide among Inuit: Results from a large, epidemiologically representative follow-back study in Nunavut, Canadian Journal of Psychiatry-Revue Canadienne De Psychiatrie, 60(6): 268-275.

DECALUWE, Beatrice et al.

2015 Impact of Inuit customary adoption on behavioral problems in school-age Inuit children, American Journal of Orthopsychiatry, 85(3): 250-258.

FRASER, Sarah L. et al.

2015 Changing rates of suicide ideation and attempts among Inuit youth: A gender-based analysis of risk and protective factors, Suicide and LifeThreatening Behavior, 45(2): 141-156.

MORRIS, Marika, Claire CROOKS

2015 Structural and cultural factors in suicide prevention: The contrast between mainstream and Inuit approaches to understanding and preventing suicide, Journal of Social Work Practice, 29(3): 321-338.

WEXLER, Lisa et al.

2015 Advancing suicide prevention research with rural American Indian and Alaska Native populations, American Journal of Public Health, 105(5): 891-899.

\section{Religion}

\section{LAUGRAND, Frédéric, Jarich G. OOSTEN}

2015 Inuit women in the process of the conversion to Christianity in the Canadian eastern Arctic: 1894-1945, Polar Record, 51(5): 513-529. 


\section{Santé / Health}

FORTIN, Marilyn, Richard E. BÉLANGER, Olivier BOUCHER, Gina MUCKLE

2015 Temporal trends of alcohol and drug use among Inuit of Northern Quebec, Canada, International Journal of Circumpolar Health, 74: article 29146.

GALLOWAY, Tracey, Louise JOHNSON-DOWN, Grace M. EGELAND

2015 Socioeconomic and cultural correlates of diet quality in the Canadian Arctic: Results from the 2007-2008 Inuit Health Survey, Canadian Journal of Dietetic Practice and Research, 76(3): 117-125.

LESSARD, Lily, Louise FOURNIER, Josée GAUTHIER, Diane MORIN

2015 Continuum of care for persons with common mental health disorders in Nunavik: A descriptive study, International Journal of Circumpolar Health, 74: article 27186.

RUIZ-CASTELL, Maria et al.

2015 Household crowding and food insecurity among Inuit families with schoolaged children in the Canadian Arctic, American Journal of Public Health, 105(3): E122-E132.

SHEEHY, T., F. KOLAHDOOZ, C. ROACHE, S. SHARMA

2015 Traditional food consumption is associated with better diet quality and adequacy among Inuit adults in Nunavut, Canada, International Journal of Food Sciences and Nutrition, 66(4): 445-451.

YOUNG, T. Kue, Susan CHATWOOD, Peter BJERREGAARD

2015 Observing the changing health of Circumpolar peoples, Arctic, 68: 1-5.

YOUNG, T. Kue, Carmina NG, Susan CHATWOOD

2015 Assessing health care in Canada's North: What can we learn from national and regional surveys?, International Journal of Circumpolar Health, 74: article 28436.

\section{Savoirs traditionnels / Traditional knowledge}

DOWSLEY, Martha

2015 Identity and the evolving relationship between Inuit women and the land in the eastern Canadian Arctic, Polar Record, 51(5): 536-549.

MUSTONEN, Tero

2015 Communal visual histories to detect environmental change in northern areas: Examples of emerging North American and Eurasian practices, Ambio, 44(8): 766-777. 


\section{Sociologie/ Sociology}

SCHMIDT, Rose, Charlotte HRENCHUK, Judie BOPP, Nancy POOLE

2015 Trajectories of women's homelessness in Canada's 3 northern territories, International Journal of Circumpolar Health, 74: article 29778.

\section{Tourisme / Tourism}

GRIMWOOD, Bryan S. R.

2015 Advancing tourism's moral morphology: Relational metaphors for just and sustainable Arctic tourism, Tourist Studies, 15(1): 3-26. 